DR. NATALIA ANDREA CASANOVA (Orcid ID : 0000-0001-8807-4618)

DR. LEANDRO MARTIN REDONDO (Orcid ID : 0000-0001-6785-2812)

DR. PABLO CHACANA (Orcid ID : 0000-0003-2824-8385)

Article type : JAM - Original Article

\title{
EFFICACY OF CHESTNUT AND QUEBRACHO WOOD EXTRACTS TO CONTROL SALMONELLA IN POULTRY \\ Running head: Wood extracts to Salmonella control
}

Natalia A. Casanova ${ }^{1, *}$

Leandro M. Redondo ${ }^{1,2}$

Enzo A. Redondo ${ }^{1,2}$

Patricia E. Joaquim ${ }^{1}$

Johana E. Dominguez ${ }^{1,2}$

Mariano E. Fernández-Miyakawa ${ }^{1,2}$

Pablo A. Chacana ${ }^{1}$

1- Instituto de Patobiología - UEDD IPVet, INTA-CONICET, Instituto Nacional de Tecnología Agropecuaria, Nicolas Repetto y De Los Reseros S/N, Hurlingham, Buenos Aires, Argentina

2- Consejo Nacional de Investigaciones Científicas y Técnicas, Godoy Cruz 2290, Ciudad Autónoma de Buenos Aires, Argentina

*Corresponding author: casanova.andrea@inta.gob.ar

This article has been accepted for publication and undergone full peer review but has not been through the copyediting, typesetting, pagination and proofreading process, which may lead to differences between this version and the Version of Record. Please cite this article as doi: $\underline{10.1111 / J A M .14948}$

This article is protected by copyright. All rights reserved 
ORCID: 0000-0001-8807-4618

$(+54) 1146210443,3187$
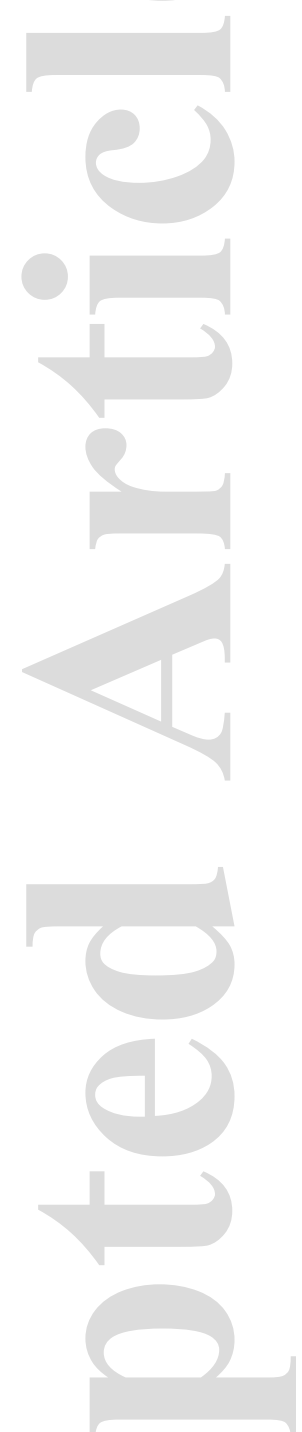

This article is protected by copyright. All rights reserved 


\section{ABSTRACT}

Aims

The study was aimed to evaluate the antibacterial activity and efficacy of chestnut and quebracho wood extracts against Salmonella by in vitro assays and in vivo trials.

Methods and results

The extracts showed inhibitory activity against Salmonella determined by the minimum inhibitory concentration method as well as on the adhesion and invasion of $S$. Gallinarum (SG) and $S$. Enteritidis (SE) in Caco-2 cells. Also, transmission electron microscopy revealed that extract-treated Salmonella showed disruption of cell walls and membranes, damage of the cytoplasm and tannin-protein aggregations. In addition, efficacy of the extracts to control SG and SE was evaluated in experimental infection trials in laying hens and broilers, respectively. SE excretion was significantly reduced on days five $(\mathrm{P}<0.01)$ and twelve $(\mathrm{P}<0.025)$ only in the quebracho group. In the fowl typhoid infection model, hens that received the chestnut extract showed a significantly reduced mortality $(\mathrm{P}<0.05)$.

Conclusions

Our results evidence that these alternative natural products may be a useful tool to control Salmonella in poultry.

Significance and impact of the study

Salmonella is a zoonotic pathogen usually associated with poultry production. This study provides information about the mechanism of antibacterial effects of chestnut and quebracho wood extracts to control Salmonella in poultry.

Keywords: Salmonella, Chestnut; Quebracho; Bioproducts, Antimicrobials, Intestinal microbiology, Food safety

\section{INTRODUCTION}

Bacteria of the genus Salmonella are zoonotic pathogens usually involved in enteric infection and disease in both humans and animals. The prevalence of Salmonella serotypes varies in different countries and during different periods of time; in addition, serotypes can emerge within a country or region and then disappear with no obvious cause or intervention measure. In poultry, Salmonella enterica serovar Gallinarum biovar Gallinarum or biovar Pullorum can cause systemic disease and

This article is protected by copyright. All rights reserved 
mortality (fowl typhoid and pullorum disease respectively) but are considered non-pathogenic for humans. Although these two diseases have been eradicated in many developed countries, they still persist and cause economic losses in the poultry industry in most developing countries (Chacana and Terzolo 2006). On the other hand, non-typhoidal or paratyphoid Salmonella infections are important zoonoses which impact on both animal production and public health; particularly $S$. Enteritidis and $S$. Typhimurium are commonly isolated from human patients (Haselbeck et al. 2017; Rukambile et al. 2019). Intensive animal production has been identified as a reservoir for non-typhoidal Salmonella. This food-borne pathogen may persist in the gastrointestinal tract of chickens and spread in the human population by the consumption of eggs, meat, and poultry by-products (Revolledo and Ferreira 2012). For example, in the last years, $S$. Heidelberg has become a relevant serotype in the poultry industry, as reported in many countries (Shah et al. 2017; Etter et al. 2019).

In the last years, several authors have reported decreased susceptibility of chicken, not only to the conventional antibiotics used in poultry production, such as ampicillin, chloramphenicol or trimethoprim-sulfamethoxazole, but also to fluoroquinolones and extended-spectrum cephalosporins (Parry and Threlfall 2008; Diarra et al. 2014). Although antibiotic treatment is not the main strategy to control Salmonella in poultry, the use of antimicrobials in low doses such as growth promoters may lead to the generation and spread of multi-resistant strains, and thus the pathogen not only serves as a gene reservoir in the gut environment but may also represent a serious threat for public health. Therefore, to reduce the risks of Salmonella contamination throughout the productive chain (feed mills, transportation, hatcheries, farms, processing plants, etc.), the industry constantly demands alternatives to antibiotics. In this context, the control of Salmonella has been addressed by several strategies, including feed additives, disinfectants, bacteriophages and vaccines (Vandeplas et al. 2010). The feed additives so far used to control Salmonella include prebiotics, probiotics, and symbiotics that modify the intestinal microbiota, and their success mainly depends on their components and the frequency of administration (Vandeplas et al. 2010). Regarding vaccines, although both inactivated (killed whole cell) and attenuated (live) vaccines are available worldwide there is not enough evidence that any of the commercial vaccines provides complete protection against all serogroups (Gast 2007). Moreover, most of these strategies are not economically feasible to be implemented in all countries (Desin et al. 2013). Thus, innovative active principles to control 
Salmonella in poultry are crucial to fulfil the constant demand for new products. In this context, natural polyphenolic compounds, such as tannins from chestnut (Castanea sativa) and quebracho (Schinopsis lorentzii) wood, have been widely evaluated due to their deleterious effects as toxic or antinutritional agents (Butler 1992) but also as potential antitumorals (Huang et al. 2010) and antimicrobials (Marín et al. 2015). These tannins, which have molar masses ranging from 300 to 20000 daltons and can be grouped as hydrolyzable or condensed according to their chemical structure (Khanbabaee and van Ree 2001) are produced by higher plants to protect them against infection, insects, or animals (Scalbert 1991). Tannins are considered as Generally Recognized As Safe (GRAS) food additives by the FDA, and are generally applied to preserve food (Molino et al. 2020). The inhibitory effects of tannins against microorganisms highly depend on their concentration and type. Several in vitro and in vivo studies have shown the activity of these polyphenols against several poultry pathogens (Cejas et al. 2011; Anderson et al. 2012), as reviewed by Diaz-Carrasco et al. (2016) and Molino et al. (2020). In addition, these polyphenols are considered as an eco-friendly alternative to antibiotics due to their ability to promote growth and modulate the gut microbiota without promoting the emergence of resistant bacteria (Redondo et al. 2014).

Based on the above, the aim of the present study was to evaluate the activity of hydrolyzable and condensed polyphenols extracted from chestnut and quebracho wood against several serotypes of Salmonella and their efficacy to control $S$. Enteritidis and $S$. Gallinarum infection in poultry.

\section{MATERIALS AND METHODS}

\section{Chestnut and quebracho extracts}

The extracts evaluated were commercially available extracts from chestnut (Castanea sativa, $>84 \%$ hydrolysable tannins) and quebracho wood (Schinopsis lorentzii, $>78 \%$ condensed tannins) supplied by Silvateam S.A., Argentina. The composition and antioxidant activity of these extracts have been characterized previously by Pizzi et al. (2009) and Molino et al. (2018) respectively. Both extracts were dissolved in sterile water, incubated at $60^{\circ} \mathrm{C}$ for $30 \mathrm{~min}$ and filtered through $0.45 \mu \mathrm{m}$ membranes.

\section{Bacterial strains}

This article is protected by copyright. All rights reserved 
A total of 15 Salmonella strains isolated from poultry (four $S$. Enteritidis, four $S$. Typhimurium, four $S$. Heidelberg, and three $S$. Gallinarum) were plated in xylose-lysine-deoxycholate agar (XLD; Oxoid) or in Brilliant Green (Oxoid) agar and incubated overnight at $37^{\circ} \mathrm{C}$. The antimicrobial susceptibility patterns of the strains are provided in the Supplementary Material.

\section{Antibacterial activity of the extracts}

Minimum inhibitory concentration (MIC), synergy test and minimal bactericidal concentration (MBC)

The antimicrobial activity of the chestnut and quebracho extracts was determined by a micro-broth dilution assay in duplicate. Sterile 96-well plates (Cell Star, Greiner Bio-one) were filled with MüllerHinton broth (MHB; Oxoid) and $100 \mu \mathrm{l}$ of the extracts was added to the first well. Two-fold serial dilutions of the extracts starting from $16 \mathrm{mg} \mathrm{ml}^{-1}$ were prepared across the plates by using a multichannel pipette. Overnight cultures of all the strains were diluted to reach the 0.5 tube of the McFarland nephelometric scale and then inoculate the microplates. Growth and purity controls were also included in each plate. Plates were incubated overnight at $37^{\circ} \mathrm{C}$, and bacterial growth was determined by the presence of a bacterial pellet. The MIC was defined as the lowest concentration of extracts that inhibited bacterial growth.

To assess the interaction between the extracts against $S$. Enteritidis (SE) and $S$. Gallinarum (SG), checkerboard titration was carried out. Tests were performed in 96-well microplates with extract concentrations ranging from $16 \mathrm{mg} \mathrm{ml}^{-1}$ to $0.125 \mathrm{mg} \mathrm{ml}^{-1}$ ( 8 to $1 / 32 \mathrm{MIC}$ ). The fractional inhibitory concentration (FIC) was calculated for each extract in each combination. The following formulas were used to calculate the FIC index (FICI): FIC of quebracho = MIC of quebracho in combination/MIC of quebracho alone, FIC of hydrolyzable chestnut $=$ MIC of chestnut in combination/MIC of chestnut alone, and FICI $=$ FIC of quebracho + FIC of chestnut. Synergy was defined as a FICI of $<0.5$, indifference was defined as a FICI between 0.5 and 4 , and antagonism was defined as a FICI $>4$. In the wells where no visible growth was detected, $10 \mu 1$ of the both was streaked onto Müller-Hinton agar and incubated overnight at $37^{\circ} \mathrm{C}$. The $\mathrm{MBC}$ was defined as the lowest concentration that completely inhibited bacterial growth.

\section{Kinetics of bacterial killing}

This article is protected by copyright. All rights reserved 
The activity of the chestnut and quebracho extracts on the growth of SE and SG was next evaluated. To this end, overnight cultures of the strains were properly diluted with MHB to render a final concentration corresponding to 0.5 McFarland, and then the extracts were added at MIC levels and thereafter incubated at $37^{\circ} \mathrm{C}$. The number of colony-forming units (CFU) in the cultures was determined after $0 \mathrm{~h}, 1 / 2 \mathrm{~h}, 1 \mathrm{~h}, 2 \mathrm{~h}, 4 \mathrm{~h}, 6 \mathrm{~h}$, and $24 \mathrm{~h}$. Ten-fold serial dilutions were prepared for each time interval and $20 \mu \mathrm{l}$ of each dilution was plated onto XLD according to Miles et al. (1938). After incubation overnight at $37^{\circ} \mathrm{C}$, the colonies were counted in duplicate. The results are expressed as $\log _{10} \mathrm{CFU} \mathrm{ml} \mathrm{m}^{-1}$ of bacterial culture.

\section{Transmission electron microscopy (TEM)}

Alterations in bacterial cell morphology were evaluated by TEM (Zeiss EM 109T) (Matijaševic et al. 2016). Bacteria in the late-exponential growth phase $\left(14 \mathrm{~h}\right.$ at $37^{\circ} \mathrm{C}$ in $\left.\mathrm{MHB}\right)$ were treated with the chestnut and quebracho extracts at the MIC level or left untreated as a control. Suspensions were incubated for $6 \mathrm{~h}$ at $37^{\circ} \mathrm{C}$, harvested by centrifugation and prefixed with $2.5 \%$ glutaraldehyde (Fluka) overnight at $4^{\circ} \mathrm{C}$. Fixed and washed cell pellets were prepared by a standard methodology that included fixation, dehydration, embedding, sectioning, and staining of sections (Matijaševic et al. 2016). Digital photomicrographs of sections of each culture were recorded.

\section{Adhesion and invasion assays}

For the adhesion and invasion assays, human-derived enterocyte-like Caco-2 cells were cultured in Dulbecco's Modified Eagle's medium (DMEM; Gibco) supplemented with heat-inactivated 10\% fetal calf serum (Gibco), 1\% non-essential amino acids (Sigma), 1\% glutamine (Sigma), and penicillinstreptomycin (100 IU ml-1 and $100 \mu \mathrm{g} \mathrm{ml} \mathrm{ml}^{-1}$ respectively; Richet) in a humidified atmosphere containing $5 \% \mathrm{CO}_{2}$ at $37^{\circ} \mathrm{C}$. Prior to infection with Salmonella strains, the Caco-2 cells were cultured until confluence, and medium was replaced with an antibiotic-free medium for $24 \mathrm{~h}$ prior to performing the adhesion and invasion assays. Salmonella strains were cultured overnight in MHB at $37^{\circ} \mathrm{C}$, and bacterial cells were recovered by centrifugation at $8000 \mathrm{~g}$ for $5 \mathrm{~min}$, washed twice with sterile phosphate-buffered saline (PBS, $\mathrm{pH} 7.3$ ) and suspended to render a concentration of $2 \times 10^{6}$ CFU ml-1 in DMEM medium. Salmonella cells were incubated at room temperature for $1 \mathrm{~h}$ with the chestnut and quebracho extracts at the MIC level or left untreated as control. According to previous results from our group (Elizondo et al. 2010), neither the chesnut nor the quebracho extracts induce

This article is protected by copyright. All rights reserved 
deleterious effects on cell monolayers at the concentrations used. After treatment with the quebracho or chestnut extracts, the bacterial suspensions were added to the cell monolayers and incubated in a humidified atmosphere containing $5 \% \mathrm{CO}_{2}$ at $37^{\circ} \mathrm{C}$ for $1 \mathrm{~h}$. For adhesion assays, after incubation, each well was washed three times with sterile PBS to remove no-adhered bacteria. Sterile distilled water was added for 15 min to lyse the Caco-2 cells and to recover attached bacteria. Finally, the bacteria were counted in duplicate on XLD agar plates. The adhesion percentage was expressed as the relation between adhered and initial bacterial count (adhered plus non-adhered bacteria). For invasion assays, the infected cells were washed twice with PBS before the addition of DMEM containing 150 $\mu \mathrm{g} \mathrm{ml} \mathrm{m}^{-1}$ gentamicin (Sigma) and incubated at $37^{\circ} \mathrm{C}$ for $60 \mathrm{~min}$ to inactivate extracellular bacteria that had not invaded the cells. Caco-2 cells were lysed and bacteria were counted as described for the adhesion assays. Two independent adherence and invasion assays were carried out for each extract and strain.

\section{Microscopic agglutination test}

To evaluate the ability of the polyphenols to agglutinate Salmonella, overnight cultures of the strains were centrifuged and pellets were resuspended in PBS until they reached 0.5 Mc Farland turbidity. Suspensions were treated with quebracho and chestnut extracts ( $1 / 2 \mathrm{MIC}, 1 \mathrm{MIC}, 2 \mathrm{MIC})$ and incubated at room temperature for $1 \mathrm{~h}$. Then, $10 \mu \mathrm{l}$ of each treatment was dropped on a slide and examined under a dark-field microscope (Olympus $\mathrm{B} \times 50$ ). PBS was included as negative control and commercial antiserum against Salmonella was used as a positive control. The end-point titer was determined as the lowest dilution of the extracts needed for an evident microscopic agglutination.

\section{Challenge trials}

\section{Feed and water}

In all cases, commercial feed free of antibiotics and coccidiostats and drinking water were provided ad libitum. Throughout the trials, feed and water were confirmed to be Salmonella-free by bacteriological analysis.

\section{Infective strains and preparation of the inocula}

SE strain INTA86 and SG strain INTA91, previously isolated from chickens suffering from paratyphoid and fowl typhoid respectively, were used for the challenge trials. To prepare the infectious inocula, strains were incubated overnight at $37^{\circ} \mathrm{C}$ in Brain Heart Infusion. Thereafter, ten- 
fold dilutions were plated onto XLD and incubated overnight to determine the number of CFU $\mathrm{ml}^{-1}$. Cultures of the challenge strains were kept at $4{ }^{\circ} \mathrm{C}$ overnight, and the bacterial suspensions were diluted in $1 \mathrm{ml}$ of PBS to reach a final concentration of $1 \times 10^{7} \mathrm{CFU} \mathrm{ml}^{-1}$ for SE and $1 \times 10^{5} \mathrm{CFU} \mathrm{ml}^{-1}$ for SG. Infectious doses were selected according to previous trials (Chacana and Terzolo 2006).

\section{Salmonella Enteritidis infection and sampling}

To assess the efficacy of the extracts against a paratyphoidal infection in broilers, 45 one-day-old Salmonella-free COBB chicks were challenged with the SE strain INTA86, a pathogenic strain of SE previously isolated from a broiler's farm. Chicks were housed in individual cages under a conventional lighting scheme. Groups of 15 chickens were fed from the first day of life with regular feed added with $0.1 \% \mathrm{w} / \mathrm{w}$ of the chestnut or quebracho extracts, at a dose based on the results of previously reported nutritional trials (Diaz-Carrasco et al. 2018). In addition, other 15 birds that received only regular feed were included as controls. On day six, chickens were individually challenged by oral gavage with $1 \times 10^{7} \mathrm{CFU}$ of SE. To determine the shedding levels of the challenge strain, birds were kept in observation for 12 days and then euthanized. On days five and twelve postinfection, all birds were sampled by individual cloacal swabbing. Swabs were directly deposited into tubes containing $4 \mathrm{ml}$ of tetrathionate broth and after $48 \mathrm{~h}$ incubation at $37^{\circ} \mathrm{C}$, an aliquot was plated onto XLD agar plus tergitol four $\left(4.6 \mathrm{ml} \mathrm{l}^{-1}\right)$ to reisolate the strain. Salmonella-like colonies were confirmed by agglutination with polyvalent antisera.

\section{Salmonella Gallinarum infection and sampling}

The fowl tyhoid infection model was carried out using 16-week old Lohmann Brown Classic Salmonella-free laying hens $(\mathrm{n}=42)$, which were maintained in individual cages following the nutritional and lighting scheme recommended by Lohmann Tierzucht GmbH (Cuxhaven, Germany). Hens were assigned into three groups of 14 birds each. Hens from the control group received commercial feed and hens from treated groups received normal feed plus $0.1 \%$ of the chestnut extract or $0.1 \%$ of the quebracho extract. Treatment with the extracts started $24 \mathrm{~h}$ before challenge. All hens were orally challenged with 1 x $10^{5} \mathrm{CFU}$ of SG. Mortality was recorded daily for 14 days and hens that remained alive were euthanized. The livers from all dead or euthanized hens were examined to re-isolate the strain onto brilliant green agar plates (Chacana and Terzolo 2006)

\section{Statistical analysis}

This article is protected by copyright. All rights reserved 
Results were statistically analyzed by means of the GraphPad software. A two-tailed Student's test was used to evaluate the activity of each extract on the growth of Salmonella through analysis of the area under the curve. The results of the adhesion and invasion assays are expressed as the mean $\pm \mathrm{SD}$ of two independent assays. Data were subjected to a one-way analysis of variance (ANOVA) followed by a Tukey's post-hoc test. Fisher's exact test was used to determine significant differences between the number of Salmonella-excreting birds or mortality rates from the treated and control group for each day post-infection analyzed. Differences with P-values below 0.05 were considered to be statistically significant.

\section{Animal welfare}

Trials were carried out in accordance with the Guidelines for the Care and Use of Experimental Animals from the National Institute of Agricultural Technology of Argentina (INTA) and protocols were approved by the Institutional Animal Care and Use Committee of the Centro de Investigaciones en Ciencia Veterinarias y Agronómicas (CICVyA) (approval \# 1/2016 and 23/2016). Euthanasia was performed by cervical dislocation.

\section{RESULTS}

\section{Antibacterial activity of chestnut and quebracho extracts}

The strains of Salmonella included in this work belonged to serotypes relevant in the poultry industry worldwide. The MICs of chestnut and quebracho extracts were determined for all the strains. The MICs for the chestnut extract ranged from $2 \mathrm{mg} \mathrm{ml}^{-1}$ to $4 \mathrm{mg} \mathrm{ml}^{-1}$ whereas those for the quebracho extract ranged from $1 \mathrm{mg} \mathrm{ml}^{-1}$ to $4 \mathrm{mg} \mathrm{ml}^{-1}$ (Table 1). Considering the MIC values, two representative isolates of non-typhoidal and typhoidal Salmonella (SE strain INTA86 and SG INTA91) were selected for further experiments. The growth curves are shown in Figure 1. The bacteriostatic effect of the extracts was determined using the previously determined MICs. In comparison to untreated cells, the viability of Salmonella was reduced by both extracts (SE: $\mathrm{P}<0.05$ chestnut vs control; $\mathrm{P}<0.01$ quebracho vs control and SG: $\mathrm{P}<0.05$ chestnut or quebracho vs control). The $\mathrm{MBC}$ for both extracts was lower for SG than for SE ( $8 \mathrm{mg} \mathrm{ml}^{-1}$ vs. $16 \mathrm{mg} \mathrm{ml}^{-1}$ ) and synergistic effects were observed when the extracts were combined $(\mathrm{FICI}=0.5)$. In both cases, the activity of the mixture was four times higher than when the extracts were tested separately. The highest antibacterial effect against SE was

This article is protected by copyright. All rights reserved 
observed when the extracts were mixed equally, whereas the highest antibacterial effect against SG was observed when the extracts were combined at a ratio of 88:12.

\section{TEM observation}

The TEM micrographs of untreated cells showed a regular rod-shaped structure with an undamaged and slightly waved outer membrane. The intracellular content was well-preserved with the cytoplasmic membrane lying close to the cell wall. The periplasmic space was thin and homogeneous while the intracellular region displayed heterogeneous electron density (Figure 2a-b). After treatment with 1 MIC of quebracho or chestnut extracts, multiple changes in the cell morphology were observed. The main observations include disruption of the cell wall, lysis of the cell membrane, damage of the cytoplasm and cell deformation. The components of the bacterial cell envelope were deformed and scattered from their original form and the intracellular structures were disorganized (Figure 2c-d). In many cells, the interaction between both extracts and the cell wall was evident, as determined by their aggregation on the surface of the outer membrane and in the cytoplasm (Figure 2e-f). Also, draining out of the intracellular contents due to rupture of the cell envelope (mostly the polar regions) was observed. Furthermore, some cells were found without membranes.

\section{Adhesion and invasion of intestinal cells}

To evaluate additional inhibitory effects of the quebracho and chestnut extracts on Salmonella pathogenesis, SG or SE treated with sub-inhibitory concentrations of the extracts were used to infect Caco-2 cells monolayers. The adhesion and invasion of SG were respectively reduced by $38.8 \pm 6 \%$ $(\mathrm{P}<0.05)$ and $100 \%$ by the chestnut extract and by $73.7 \pm 5 \%(\mathrm{P}<0.001)$ and $95 \pm 5 \%(\mathrm{P}<0.001)$ by the quebracho extract. Regarding SE, its adhesion was not affected by the chestnut extract, but was increased by the quebracho extract. In contrast, its invasion was reduced by $98.6 \pm 0.1 \%(\mathrm{P}<0.001)$ by the chestnut extract and by $99.1 \pm 0.6 \%(\mathrm{P}<0.001)$ by the quebracho extract.

\section{Microscopic agglutination test}

Salmonella isolates exhibited heterogeneous profiles of micro-agglutination. The agglutination titers of the chestnut and quebracho extracts for all non-typhoidal strains were of $1 \mathrm{mg} \mathrm{ml}^{-1}$ or $2 \mathrm{mg} \mathrm{ml}^{-1}$ ( 0.5 of the MIC value) whereas those for the SG strains were similar to $1 \mathrm{MIC}\left(2 \mathrm{mg} \mathrm{ml}^{-1}\right)$ for all SG tested strains. In all cases, no macro-agglutination was observed.

\section{Effects of the extracts on Salmonella infection in poultry}

This article is protected by copyright. All rights reserved 
To evaluate the performance of the chestnut and quebracho extracts against Salmonella in vivo, trials were carried out using the typhoidal and non-typhoidal infection models in broilers or laying hens. Until the challenge trials, all the birds remained healthy and free of any external Salmonella infection and feed and drinking water were negative for Salmonella spp.

In the group that received feed supplemented with quebracho extract, SE excretion was significantly lower on days $5(3 / 15, \mathrm{P}<0.01)$ and $12(5 / 15, \mathrm{P}<0.025)$ post-infection compared to control group (11/15 and 12/15, respectively) whereas in the group supplemented with the chestnut extract, SE excretion was not reduced $(\mathrm{P}=1.00)$. In contrast, only the chestnut extract was able to significantly reduce the mortality of the hens due to fowl typhoid. The mortality rate in the control group was of $71 \%(10 / 14)$, whereas that in the chestnut and quebracho groups was of $36 \%(5 / 14 ; \mathrm{P}=0.0465)$ and $50 \%(7 / 14 ; \mathrm{P}=0.1886)$ respectively (Figure 3$)$. SG was re-isolated from the liver of all birds that died from fowl typhoid but from none of the hens that remained alive at the end of the trial.

\section{DISCUSSION}

The control of Salmonella in poultry is complex because this bacterium can enter the production chain through different ways. In productive conditions, it is crucial to reduce the excretion of Salmonella from infected animals at early stages to control contamination in the environment. Moreover, control measures that have successfully eradicated SG (Anderson et al. 2006) are usually useless and not applicable to the eradication of other serovars with impact in public health. The risk of contamination in the farm can be reduced not only by biosecurity management, but also by using several products such as organic acids, probiotics, disinfectants, vaccines, and phytochemicals. In this work, commercial chestnut and quebracho wood extracts were evaluated against four serovars of Salmonella of importance in poultry worldwide.

The MIC values and inhibitory activity (bacteriostatic or bactericidal, concentration-dependent effect) for the chestnut and quebracho extracts determined in this work were similar to those found in other studies and suggest that tannins may interfere with basic cellular functions, like energy metabolism or cause physical damage to cells (Taguri et al. 2004; Van Parys et al. 2008; Costabile et al. 2011). Furthermore, we detected a synergistic interaction between quebracho and chestnut extracts to inhibit

This article is protected by copyright. All rights reserved 
the growth of Salmonella as suggested by the decrease in the MIC values when both phytochemicals were combined. The mechanisms underlying the synergistic actions observed are not yet known, but may be related to the presence of multiple bioactive molecules, as described in previous works (Redondo et al. 2014; Molino et al. 2018). Besides their inhibitory effects against the growth of Salmonella, chestnut and quebracho extracts also interfered with the adhesion and invasion of the microorganism towards epithelial cells, which are critical for the interaction between the bacteria and the host. A distinction must be done between SE as a non-typhoidal serotype for chickens and SG. While adhesion to enterocytes is critical for the survival and multiplication of SE in the gut, SG interacts with the enterocyte to invade the cell and then reach the lamina propria (Gal-Mor et al. 2014). To survive in hostile environments or in the presence of inhibitory substances, Salmonella can activate virulence factors as stress-responses, which results in increased adhesion without affecting its invasion into the organs (Chakroun et al. 2018; Estrada-Acosta et al. 2018). This potential upregulation of adhesion effectors seems to depend on each single serotype or strain and may explain that, in this work, quebracho extracts unexpectedly increased the adhesion of SE to Caco-2 cells.

TEM micrographs revealed electron-dense aggregations on the cell surface, disruption of the wall and lysis of the membrane of treated bacteria (mainly in SE), which indicates the interaction between both extracts and the outer membranes. The enhanced permeability of the membrane may explain the deposits of the phytochemicals observed inside the cytoplasm together with morphological cell changes that may lead to the microorganism death. Similar interactions between cell structures of Gram-negative bacteria and tannins have been described by several authors (Funatogawa et al. 2004; Wang et al. 2012; Liu et al. 2013). In this way, TEM findings support the results obtained by the micro-agglutination assays, where a lower amount of tannins was needed to agglutinate SG. Tannins are biological molecules known by their abillity to precipitate or form complexes with proteins and these arrangements depend not only on the structure of tannins and proteins but also on their composition, concentration and source (Khanbabaee and van Ree 2001). Thus, a likely explanation of these findings may rely on the fact that SG is the only Salmonella serotype lacking flagella (Chacana and Terzolo 2006) and thus fewer amounts of proteins are available on the cell surface to interact with the extracts.

This article is protected by copyright. All rights reserved 
Although both the chestnut and quebracho extracts showed similar activity against SE and SG in vitro, they had different performance in the challenge trials in vivo. While the quebracho extracts was effective to reduce SE excretion, the chestnut extract was effective to reduce the mortality due to fowl typhoid. These results should be interpreted considering the differences between SE and SG pathogenesis in chickens (Kaiser et al. 2000) and the multiple biological effects of phytochemicals which involve anti-inflammatory, antioxidant, antiviral, and antibacterial properties among others (Frankel et al. 1993; Teissedre et al. 1996; Santos-Buelga and Scalbert 2000). In this way, it is also relevant to consider that in vivo effects depend on multiple interactions between the active molecules of the extracts, the digestive processes, and the phytochemical-derived metabolites produced by the gut microbiota (Molino et al. 2018). The failure of the chestnut extract to reduce SE shedding observed in our work could be due to a lack of local effects of hydrolyzable tannins in the cecum, the gut segment that is mostly colonized by SE (Ricke 2003; Khan 2014). Similarly, Van Parys et al. (2008) found that although sweet chestnut wood extract had strong antibacterial activity against $S$. Typhimurium in vitro, it had no effect on the fecal excretion or colonization of the pathogen in pigs. In contrast, the condensed tannins from quebracho wood are less susceptible to gastrointestinal hydrolysis and can pass through the small intestine mostly intact to be further metabolized by the gut microbiota (Santos-Buelga and Scalbert 2000; Rios et al. 2002). These products are known to have both anti-inflammatory and anti-oxidant properties (Serrano et al. 2009; Sieniawska and Baj 2016; Smeriglio et al. 2017; Molino et al. 2018) which could help to reduce the colonization or excretion of the microorganism. In this regard, Varmuzova et al. (2015) reported that feed supplemented with polyphenols, particularly flavonoids, from Curcuma and Scutellaria allows decreasing SE colonization and gut inflammation. On the other hand, only the chestnut extract was able to reduce the mortality due to fowl typhoid. Unlike SE, SG is a more invasive serovar and normally does not induce high inflammatory response or intestinal damage. In fact, SG infection may not be limited by the mucosal immune system and can cause severe systemic disease (Kaiser et al. 2000). Since hydrolyzable tannins from chestnut or their metabolites have strong reducing and antioxidant capacity (Molino et al. 2018) and could be absorbed through the gastrointestinal tract more easily than polyphenols of higher molecular weight (Santos-Buelga and Scalbert 2000), they may have interfered with the invasion of SG into the target organs.

This article is protected by copyright. All rights reserved 
In conclusion, our study evidences that the use of chestnut and quebracho extracts may be helpful to control Salmonella in poultry including multi-resistant strains that represent a serious threath for public health (Mouttotou et al. 2017). As mentioned, although the control of food-borne Salmonella does not rely on the use of antibiotics, the inappropriate use of antibiotics favors the emergence of resistant strains. In this context, several global organizations such as WHO, FAO and the OIE are urging countries to promote the responsible and prudent use of antimicrobials as well as approaches to decrease the use of antibiotics in animal production (OIE 2016). Also, the consumers' growing demand for eco-friendly products will have a critical impact on the poultry industry in the forthcoming years. Together with monitoring and appropriate biosecurity management programs, the use of natural feed aditives can help to maintain and improve productivity as well as to guarantee food safety for the population.

\section{ACKNOWLEDGEMENTS}

We thank Instituto Nacional de Tecnología Agropecuaria and the Consejo Nacional de Investigaciones Científicas y Tecnológicas, Argentina, for support and Silvateam S.A., Argentina, for providing the commercial tannin products used in the experiments. We also thank Ms. Jesica S. Bucci and Mr. Ignacio de la Fuente for their help at the lab and maintenance of the animals and Dr. Horacio Terzolo for his valuable comments to improve the manuscript.

\section{CONFLICT OF INTEREST STATEMENT}

Some of the authors provide consulting services to companies related to poultry nutrition.

\section{REFERENCES}

Anderson, L. A., Miller, D. A., and Trampel, D. W. (2006). Epidemiological investigation, cleanup, and eradication of pullorum disease in adult chickens and ducks in two small-farm flocks. Avian Dis 50, 142-147. https://doi.org/10.1637/7397-062105R.1

Anderson, R. C., Vodovnik, M., Min, B. R., Pinchak, W. E., Krueger, N. A., Harvey, R. B., and

Nisbet, D. J. (2012). Bactericidal effect of hydrolysable and condensed tannin extracts on Campylobacter jejuni in vitro. Folia Microbiologica 57, 253-258. https://doi.org/10.1007/s12223012-0119-4

This article is protected by copyright. All rights reserved 
Butler, L. G. (1992). Antinutritional effects of condensed and hydrolyzable tannins. Basic Life Sci 59, 693-698. https://doi.org/10.1007/978-1-4615-3476-1_40

Cejas, E., Pinto, S., Prosdocimo, F., Batalle, M., Barrrios, H., Tellez, G., and De-Franceschi, M. (2011). Evaluation of quebracho red wood (Schinopsis lorentzii) polyphenols vegetable extract for the reduction of coccidiosis in broiler chicks. Int J Poult Sci 10, 344-349.

Chacana, P.A., Terzolo, H.R. (2006). Protection conferred by a live Salmonella Enteritidis vaccine against fowl typhoid in laying hens. Avian Dis 50, 280-3. https://doi.org/ 10.1637/7463-102705R.1

Chakroun, I., Mahdhi, A., Morcillo, P., Cordero, H., Cuesta, A., Bakhrouf, A., Mahdouani, K., and Esteban, M. Á. (2018). Motility, biofilm formation, apoptotic effect and virulence gene expression of atypical Salmonella Typhimurium outside and inside Caco-2 cells. Microb Pathog 114, 153-162. https://doi.org/10.1016/j.micpath.2017.11.010

Costabile, A., Sanghi, S., Martín-Pelaez, S., Mueller-Harvey, I., Gibson, G.R., Rastall, R.A., and Klinder, A. (2011). Inhibition of Salmonella Typhimurium by tannins in vitro. J Food Agric Environ 9, 119-124.

Desin, T. S., Köster, W., and Potter, A. A. (2013). Salmonella vaccines in poultry: past, present and future. Expert Rev Vaccines 12, 87-96. https://doi.org/10.1586/erv.12.138

Diarra, M. S., Delaquis, P., Rempel, H., Bach, S., Harlton, C., Aslam, M., Pritchard, J., and Topp, E. (2014). Antibiotic resistance and diversity of Salmonella enterica serovars associated with broiler chickens. J Food Protect 77, 40-49. https://doi.org/10.4315/0362-028.JFP-13-251

Diaz Carrasco, J. M., Redondo, L. M., Redondo, E. A., Dominguez, J. E., Chacana, A. P., and Fernandez Miyakawa, M. E. (2016). Use of Plant Extracts as an Effective Manner to Control Clostridium perfringens Induced Necrotic Enteritis in Poultry. BioMed Res Int 3278359. https://doi.org/10.1155/2016/3278359

Elizondo, A. M., Mercado, E. C., Rabinovitz, B. C., and Fernandez-Miyakawa, M. E. (2010). Effect of tannins on the in vitro growth of Clostridium perfringens. Vet Microbiol 145, 308-314. https://doi.org/10.1016/j.vetmic.2010.04.003

Estrada-Acosta, M. D., Ramirez, K., Medrano-Félix, J. A., Castro-Del Campo, N., López-Moreno, H. S., Jimenez Edeza, M., Martínez-Urtaza, J., and Chaidez, C. (2018). Effect of river water exposition

This article is protected by copyright. All rights reserved 
on adhesion and invasion abilities of Salmonella Oranienburg and Saintpaul. Int J Environ Health Res 28, 43-54. https://doi.org/10.1080/09603123.2017.1415308

Etter, A. J., West, A. M., Burnett, J. L., Wu, S. T., Veenhuizen, D. R., Ogas, R. A., and Oliver, H. F. (2019). Salmonella enterica subsp. enterica Serovar Heidelberg Food Isolates Associated with a Salmonellosis Outbreak Have Enhanced Stress Tolerance Capabilities. Appl Environ Microbiol 85, e01065-19. https://doi.org/10.1128/AEM.01065-19

Frankel, E. N., Kanner, J., German, J. B., Parks, E., and Kinsella, J. E. (1993). Inhibition of oxidation of human low-density lipoprotein by phenolic substances in red wine. Lancet (London, England) 341, 454-457. https://doi.org/10.1016/0140-6736(93)90206-V

Funatogawa, K., Hayashi, S., Shimomura, H., Yoshida, T., Hatano, T., Ito, H., and Hirai, Y. (2004). Antibacterial activity of hydrolyzable tannins derived from medicinal plants against Helicobacter pylori. Microbiol Immunol 48, 251-261. https://doi.org/10.1111/j.1348-0421.2004.tb03521.x

Gal-Mor, O., Boyle, E. C., and Grassl, G. A. (2014). Same species, different diseases: how and why typhoidal and non-typhoidal Salmonella enterica serovars differ. Front Microbiol 5, 391. https://doi.org/10.3389/fmicb.2014.00391

Gast R. K. (2007). Serotype-specific and serotype-independent strategies for preharvest control of food-borne Salmonella in poultry. Avian Dis 51, 817-828. https://doi.org/10.1637/8090-081807.1

Haselbeck, A. H., Panzner, U., Im, J., Baker, S., Meyer, C. G., and Marks, F. (2017). Current perspectives on invasive nontyphoidal Salmonella disease. Curr Opin Infect Dis 30, 498-503. https://doi.org/10.1097/QCO.0000000000000398

Huang, W. Y., Cai, Y. Z., and Zhang, Y. (2010). Natural phenolic compounds from medicinal herbs and dietary plants: potential use for cancer prevention. Nutr and Cancer 62(1), 1-20. https://doi.org/10.1080/01635580903191585

Kaiser, P., Rothwell, L., Galyov, E. E., Barrow, P. A., Burnside, J., and Wigley, P. (2000). Differential cytokine expression in avian cells in response to invasion by Salmonella Typhimurium, Salmonella Enteritidis and Salmonella Gallinarum. Microbiology (Reading, England) 146, 32173226. https://doi.org/10.1099/00221287-146-12-3217

This article is protected by copyright. All rights reserved 
Khan C. M. (2014). The Dynamic Interactions between Salmonella and the Microbiota, within the Challenging Niche of the Gastrointestinal Tract. Int Sch Res Notices 846049. https://doi.org/10.1155/2014/846049

Khanbabaee, K., and van Ree, T. (2001). Tannins: classification and definition. Nat Prod Rep 18, 641-649. https://doi.org/10.1039/b1010611

Liu, X. L., Hao, Y. Q., Jin, L., Xu, Z. J., McAllister, T. A., and Wang, Y. (2013). Anti-Escherichia coli $\mathrm{O} 157: \mathrm{H} 7$ properties of purple prairie clover and sainfoin condensed tannins. Molecules (Basel, Switzerland) 18, 2183-2199. https://doi.org/10.3390/molecules 18022183

Magiorakos, A. P., Srinivasan, A., Carey, R. B., Carmeli, Y., Falagas, M. E., Giske, C. G., Harbarth, S., Hindler, J. F., Kahlmeter, G., Olsson-Liljequist, B., Paterson, D. L., Rice, L. B., Stelling, J., Struelens, M. J., Vatopoulos, A., Weber, J. T., and Monnet, D. L. (2012). Multidrug-resistant, extensively drug-resistant and pandrug-resistant bacteria: an international expert proposal for interim standard definitions for acquired resistance. Clin Microbiol Infect 18, 268-281. https://doi.org/10.1111/j.1469-0691.2011.03570.x

Marín, L., Miguélez, E. M., Villar, C. J., and Lombó, F. (2015). Bioavailability of dietary polyphenols and gut microbiota metabolism: antimicrobial properties. BioMed Res Int 905215. https://doi.org/10.1155/2015/905215

Matijašević, D., Pantić, M., Rašković, B., Pavlović, V., Duvnjak, D., Sknepnek, A., and Nikšić, M. (2016). The Antibacterial Activity of Coriolus versicolor Methanol Extract and Its Effect on Ultrastructural Changes of Staphylococcus aureus and Salmonella Enteritidis. Front Microbiol 7, 1226. https://doi.org/10.3389/fmicb.2016.01226

Miles, A. A., Misra, S. S., and Irwin, J. O. (1938). The estimation of the bactericidal power of the blood. J Hyg (London) 38, 732-749. https://doi.org/10.1017/s002217240001158x

Molino, S., Fernández-Miyakawa, M., Giovando, S., and Rufián-Henares, J.A. (2018). Study of antioxidant capacity and metabolization of quebracho and chestnut tannins through in vitro gastrointestinal digestion-fermentation. J Funct Foods 49,188-195.

Molino, S., Casanova, N. A., Rufián Henares, J. Á., and Fernandez Miyakawa, M. E. (2020). Natural Tannin Wood Extracts as a Potential Food Ingredient in the Food Industry. $J$ Agr Food Chem 68, 2836-2848. https://doi.org/10.1021/acs.jafc.9b00590

This article is protected by copyright. All rights reserved 
Mouttotou, N., Ahmad, S., Kamran, Z., and Koutoulis, K.C. (2017). Prevalence, Risks and Antibiotic Resistance of Salmonella in Poultry Production Chain. In Current Topics in Salmonella and Salmonellosis. Chapter 12, ed. Mares, M (Rijeka: Intech) 215-234. https://doi.org/10.5772/67438 OIE, 2016. Resolutions of the 84th OIE General Session, Resolution No.36. Combating Antimicrobial Resistance through a One Health Approach: Actions and OIE Strategy. Available from: goo.gl/PFKWJo

Parry, C. M., and Threlfall, E. J. (2008). Antimicrobial resistance in typhoidal and nontyphoidal salmonellae. Curr Opin Infect Dis 21, 531-538. https://doi.org/10.1097/QCO.0b013e32830f453a

Pizzi, A., Pasch, H., Rode, K., and Giovando, S. (2009). Polymer structure of commercial hydrolysable tannins by matrix assisted laser desorption ionization time of flight mass spectrometry. $J$ Appl Polym Sci 113, 3847-3859

Redondo, L. M., Chacana, P. A., Dominguez, J. E., and Fernandez Miyakawa, M. E. (2014). Perspectives in the use of tannins as alternative to antimicrobial growth promoter factors in poultry. Front Microbiol 5, 118. https://doi.org/10.3389/fmicb.2014.00118

Revolledo, L. and Ferreira, A.J.P. (2012). Current perspectives in avian salmonellosis: Vaccines and immune mechanisms of protection. J Appl Poult Res 21, 418-431. https://doi.org/10.3382/japr.201100409

Ricke S. C. (2003). The gastrointestinal tract ecology of Salmonella enteritidis colonization in molting hens. Poult Sci 82, 1003-1007. https://doi.org/10.1093/ps/82.6.1003

Rios, L. Y., Bennett, R. N., Lazarus, S. A., Rémésy, C., Scalbert, A., and Williamson, G. (2002).

Cocoa procyanidins are stable during gastric transit in humans. Am J Clin Nutr 76, 1106-1110. https://doi.org/10.1093/ajen/76.5.1106

Rukambile, E., Sintchenko, V., Muscatello, G., Kock, R., and Alders, R. (2019). Infection, colonization and shedding of Campylobacter and Salmonella in animals and their contribution to human disease: A review. Zoonoses Public Health 66, 562-578. https://doi.org/10.1111/zph.12611

Santos-Buelga, C. and Scalbert, A. (2000). Proanthocyanidins and tannin-like compounds - nature, occurrence, dietary intake and effects on nutrition and health. J Sci Food Agric 80, 10941117.http://doi.org/10.1002/(SICI)1097-0010(20000515)80:7<1094::AID-JSFA569>3.0.CO;2-1

This article is protected by copyright. All rights reserved 
Scalbert, A. (1991). Antimicrobial properties of tannins. Phytochemistry 30, 3875-3883. https://doi.org/10.1016/0031-9422(91)83426-L

Serrano, J., Puupponen-Pimiä, R., Dauer, A., Aura, A.M., and Saura-Calixto, F. (2009). Tannins: Current Knowledge of Food Sources, Intake, Bioavailability and Biological Effects. Mol Nutr Food Res 53, 310-329.

Shah, D.H., Paul, N.C., Sischo, W.C., Crespo, R., and Guard, J. (2017). Population dynamics and antimicrobial resistance of the most prevalent poultry-associated Salmonella serotypes. Poult Sci 96, 687-702. doi:10.3382/ps/pew342

Sieniawska, E., Baj, T., 2016. Tannins; Elsevier Inc.

Smeriglio, A., Barreca, D., Bellocco, E., and Trombetta, D. (2017). Proanthocyanidins and hydrolysable tannins: occurrence, dietary intake and pharmacological effects. Br J Pharmacol 174, 1244-1262. https://doi.org/10.1111/bph.13630

Taguri, T., Tanaka, T., and Kouno, I. (2004). Antimicrobial activity of 10 different plant polyphenols against bacteria causing food-borne disease. Biol Pharm Bull 27, 1965-1969. https://doi.org/10.1248/bpb.27.1965

Teissedre, P.L., Frankel, E.N., Waterhouse, A.L., Peleg, H., German, J.B. (1996). Inhibition of invitro human LDL oxidation by phenolic antioxidants from grapes and wines. J Sci Food Agric 70, 5561. https://doi.org/10.1002/(SICI)1097-0010(199601)70:1<55::AID-JSFA471>3.0.CO;2-X

Vandeplas, S., Dubois Dauphin, R., Beckers, Y., Thonart, P., and Théwis, A. (2010). Salmonella in chicken: current and developing strategies to reduce contamination at farm level. J Food Prot 73, 774-785. https://doi.org/10.4315/0362-028x-73.4.774

Van Parys, A., Boyen, F., Dewulf, J., Haesebrouck, F., and Pasmans, F. (2010). The use of tannins to control Salmonella typhimurium infections in pigs. Zoonoses and Public Health 57, 423-428. https://doi.org/10.1111/j.1863-2378.2009.01242.x

Varmuzova, K., Matulova, M. E., Gerzova, L., Cejkova, D., Gardan-Salmon, D., Panhéleux, M., Robert, F., Sisak, F., Havlickova, H., and Rychlik, I. (2015). Curcuma and Scutellaria plant extracts protect chickens against inflammation and Salmonella Enteritidis infection. Poult Sci 94, 2049-2058. https://doi.org/10.3382/ps/pev190

This article is protected by copyright. All rights reserved 
Wang, Y., Jin, L., Ominski, K. H., He, M., Xu, Z., Krause, D. O., Acharya, S. N., Wittenberg, K. M., Liu, X. L., Stanford, K., and McAllister, T. A. (2013). Screening of condensed tannins from Canadian prairie forages for anti-Escherichia coli $\mathrm{O} 157: \mathrm{H} 7$ with an emphasis on purple prairie clover (Dalea purpurea Vent). J Food Protect 76, 560-567. https://doi.org/10.4315/0362-028X.JFP-12-259

\section{AUTHORS CONTRIBUTION STATEMENT}

N.A.C., L.M.R, M.E.F.M. and P.A.C. conceived and planned the work. N.A.C., L.M.R., E.R., P.J., and J.E.D carried out the experiments and trials. All authors contributed to the analysis and interpretation of the results. N.A.C., L.M.R. and P.A.C. wrote the original manuscript. N.A.C., L.M.R., J.E.D and P.A.C. reviewed and edited the final manuscript. All authors reviewed and approved the manuscript.

This article is protected by copyright. All rights reserved 


\section{TABLES}

Table 1. Minimal inhibitory concentration of chestnut and quebracho extracts against Salmonella strains

\begin{tabular}{ccc}
\hline Salmonella strains & \multicolumn{2}{c}{ MIC $\left(\mathrm{mg} \mathrm{ml}^{-1}\right)$} \\
Chestnut & Quebracho \\
\hline Enteritidis 1 & 2 & 4 \\
Enteritidis 2 & 2 & 4 \\
Enteritidis 3 & 2 & 4 \\
Enteritidis 4 & 2 & 4 \\
Heidelberg 1 & 2 & 4 \\
Heidelberg 2 & 2 & 4 \\
Heidelberg 3 & 2 & 4 \\
Heidelberg 4 & 2 & 4 \\
Typhimurium 1 & 4 & 4 \\
Typhimurium 2 & 2 & 4 \\
Typhimurium 3 & 4 & 4 \\
Typhimurium 4 & 2 & 4 \\
Gallinarum 1 & 2 & 2 \\
Gallinarum 2 & 2 & 2 \\
Gallinarum 3 & 2 & 1 \\
\hline
\end{tabular}

MIC: minimal inhibitory concentration

This article is protected by copyright. All rights reserved 


\section{FIGURE LEGENDS}

Figure 1. Bacteriostatic effect of quebracho and chestnut extracts on liquid cultures of Salmonella Enteritidis (a) and (b) Gallinarum. Log phase cultures were treated at MIC level. Data are expressed as mean \pm S.E.M. $(n=2)$.

MIC: minimal inhibitory concentration

(a) Control group: ( - ) ; chestnut group: $(-\bullet)$; quebracho group: $\left(-{ }^{-}\right)$; Chestnut extract versus control: $\mathrm{P}<0.05$; Quebracho extract versus control: $\mathrm{P}<0.01$

(b) Control group: ( - ); chestnut group: $(-\odot)$; quebracho group: $(-\odot)$; Chestnut extract versus control: $\mathrm{P}<0.05$; Quebracho extract versus control: $\mathrm{P}<0.05$

Figure 2. Representative transmission electron microscopy micrographs of Salmonella cells either untreated (a-b) or treated with quebracho and chestnut extracts at MIC level (c-f) MIC: minimal inhibitory concentration

Figure 3. Cumulative mortality of chicken challenged with Salmonella Gallinarum. Control group: ( $\Delta$ ); chestnut group: ( $\bigcirc$ ); quebracho group: $(\square$ ).

This article is protected by copyright. All rights reserved 


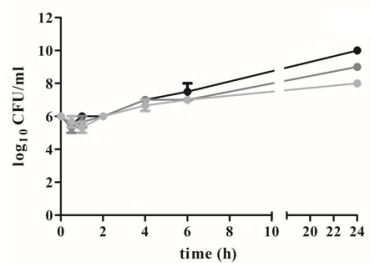

(b)

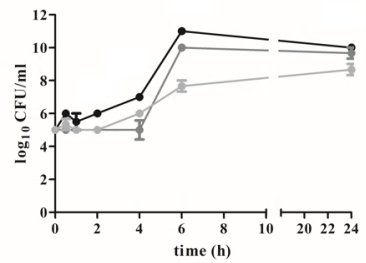

jam_14948_f1.tif

This article is protected by copyright. All rights reserved 

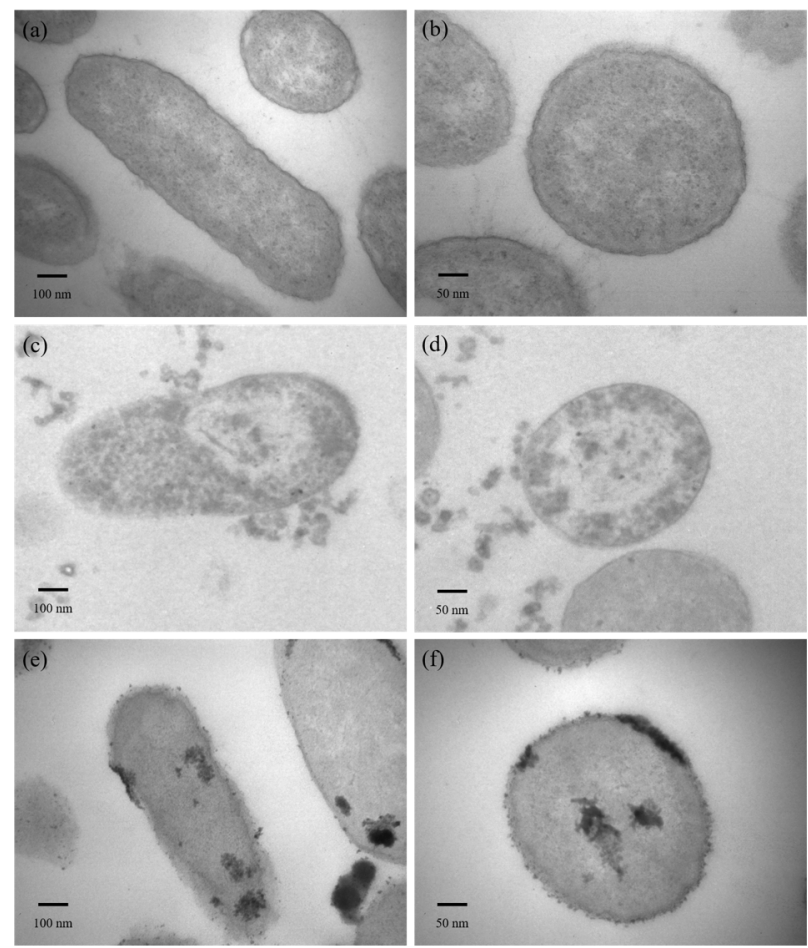

jam_14948_f2.tif 


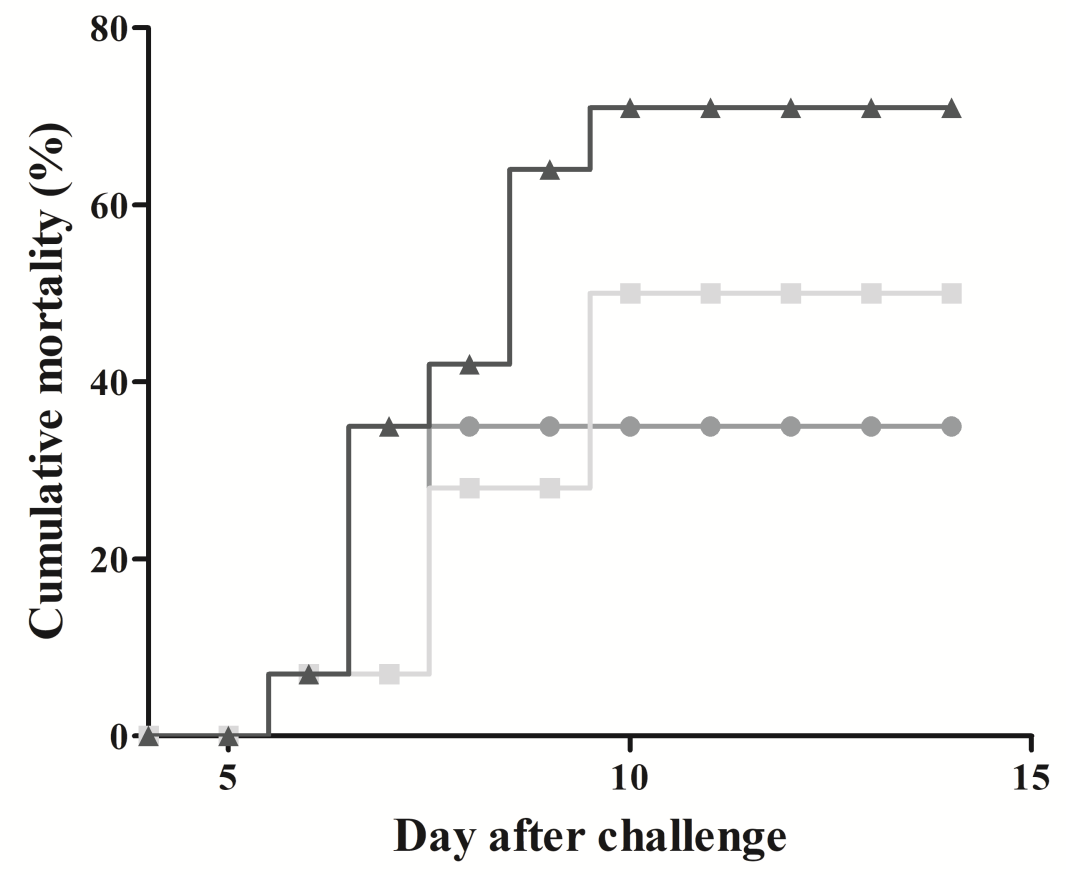

jam_14948_f3.tif

This article is protected by copyright. All rights reserved 